\author{
Research Article \\ www.ijrap.net
}

\title{
ANTIMICROBIAL ACTIVITY OF MACHILUS MACRANTHA NEES. (LAURACEAE) STEM BARK EXTRACTS
}

\author{
Anil U Tatiya $^{1 *}$, Santosh S Surana ${ }^{2}$, A. K. Saluja ${ }^{3}$, Sanjay J Surana ${ }^{4}$ \\ ${ }^{1}$ Associate Professor, Department of Pharmacognosy, R. C. Patel Institute of Pharmaceutical Education and Research, \\ Shirpur, Maharashtra, India \\ ${ }^{2}$ Assistant Professor, Department of Pharmacognosy, G.S.S.Loknete J. D. Pawar college of Pharmacy, Manur-Kalwan, \\ Nashik, Maharashtra, India \\ ${ }^{3}$ Principal, A. R. College of Pharmacy and G. H. Patel Institute of Pharmacy, Vallabh Vidhyanagar, Gujarat, India \\ ${ }^{4}$ Principal and Head, Department of Pharmacognosy, R. C. Patel Institute of Pharmaceutical Education and Research, \\ Shirpur, Maharashtra, India
}

Received on: 04/12/13 Revised on: 30/12/13 Accepted on: 08/01/14

\author{
*Corresponding author \\ Dr. Anil U Tatiya, Asst. Prof., Dept. of Pharmacognosy, R. C. Patel Institute of Pharmaceutical Education \& Research, Karvand Naka, Shirpur - \\ 425405 Dist. Dhule (M.S.) India Email: aniltatiya12171@gmail.com \\ DOI: $10.7897 / 2277-4343.05122$
}

\section{ABSTRACT}

An assessment of phytochemical composition and antimicrobial activity of different extracts of Machilus macrantha Nees. stem bark against Staphylococcus aureus NCIM 2079, Salmonella typhi NCIM 2217, Escherichia coli NCIM 2065, Pseudomonas aerugenosa NCIM 2200, and against the fungal strains Candida albicans NCIM 3471 and Aspergillus niger NCIM 3452 were done by using the two fold serial micro dilution method. Qualitative chemical test of all extracts were done by standard protocol. Alkaloids, carbohydrates, steroids and tannins were the major phytochemicals present in the plant. Results obtained showed that all the extracts had significant inhibitory effect $(\mathrm{P}<0.01)$ against tested bacteria, whereas remarkable $(\mathrm{P}<0.05)$ inhibitory effect against fungi at a concentration of 5 and $10 \mathrm{mg} / \mathrm{ml}$ comparable with control and reference standard group. Tannins containing extracts like acetone and ethyl acetate significantly $(\mathrm{P}<0.01)$ inhibited growth of micro organism against $S$. aureus while chloroform and ethyl acetate extracts showed significant $(\mathrm{P}<0.01)$ inhibition against $S$. typhi, E. coli and P. aeruginosa at the conc. of $10 \mathrm{mg} / \mathrm{ml}$. In addition, the acetone and pet ether extracts exhibited a significantly inhibition on $C$. albicans and $A$. niger. The significant MIC value for the microorganisms (E. coli, P. aerugenosa) sensitive to the extract was $1 \mathrm{mg} / \mathrm{ml}$. The overall MIC of extracts was in between 1-6 mg/ml. These results provided a rationalization for the traditional use of this plant in the treatment of infectious diseases.

Keywords: Machilus macrantha; lauraceae, Antimicrobial activity

\section{INTRODUCTION}

Plants remain the most common source of anti microbial agents. Their usage, as traditional health remedies, is the most popular for $80 \%$ of world population in Asia, Latin America and Africa. Herbs are reported to have minimal side effects. In recent years, pharmaceutical companies have spent a lot of time and money in developing natural products extracted from plants, to produce more cost effective remedies that are affordable to the population. The rising incidence in multidrug resistance amongst pathogenic microbes has further necessitated the need to search for newer antibiotic sources ${ }^{1}$. Several members of the genus Machilus are being used traditionally for wide variety of ethno-pharmacological properties. The plant of Machilus macrantha Nees (Lauraceae), commonly known as Gulmau, is a large tree grows up to $27 \mathrm{~m}$ in height, found in Bihar and Deccan peninsula (Western Ghats of Maharashtra, India). The bark is used in pleurisy, asthma and rheumatism ${ }^{2}$. The leaves are also used externally in the treatment of ulcers ${ }^{3,4}$. The bark of Machilus macrantha Nees has a pleasant odour, is cheap substitute for cinnamomum iners. The bark is a rich source of mucilage ${ }^{5}$. Anti-inflammatory activity of bark has also been reported ${ }^{6}$. As a result of indiscriminate use of antimicrobial drugs in the treatment of infectious diseases, microorganisms have developed resistance to many antibiotics. There is need to develop alternative antibiotic drugs from natural origin. One approach is to screen local medicinal plants which represent rich source of novel antimicrobial agents. The present study was carried out to investigate the antimicrobial properties of Machilus macrantha extracted by various solvents. Inhibitory effect by zone of inhibition and minimum inhibitory concentration (MIC) were carried out in this study.

\section{MATERIALS AND METHODS}

Plant Collection and Authentication

Machilus macrantha Nees. (Lauraceae) stem barks were collected from Lonavala, Pune district, Maharashtra, India. The plant was authenticated by the Scientists of Botanical Survey of India, Pune, (M.S.), India. A voucher specimen (No.37) has been deposited in the Department of Pharmacognosy.

\section{Plant preparation and Extraction}

Air dried stem bark of Machilus macrantha was grounded (hammer mill) and coarsely powdered. $100 \mathrm{~g}$ air dried bark powdered of Machilus macrantha was successively extracted with various solvents like petroleum ether (4060 ), chloroform, acetone, ethyl acetate and aqueous by using soxhlet extractor. The extract were filtered with whatman No.1 filter paper and concentrated in vacuum below $40^{\circ} \mathrm{C}$ to give the crude extracts used for further investigation. 


\section{Preliminary Phytochemical tests}

Phytochemical screening of all the extracts for presence of alkaloids, steroids, carbohydrates and tannins were carried out as described by Bruneton? .

\section{Test micro-organism and Media}

The bacterial strains used in the study were Staphylococcus aureus NCIM 2079, S. typhi NCIM 2217, Escherichia coli NCIM 2065, Pseudomonas aerugenosa NCIM 2200,while the fungal strains were Candida albicans NCIM 3471 and Aspergillus niger NCIM 3452. All the bacterial strains were grown and maintained on nutrient agar slants. The inoculum size of each test strain was $1 \times 10^{8}$ bacteria $/ \mathrm{ml}$ for disc diffusion assay which was standardized by adjusting the optical density of the bacterial suspension to turbidity corresponding to spectrophotometric absorbance $=0.5$ at $540 \mathrm{~nm}$.

\section{Screening for anti microbial activity}

Disc diffusion method was carried out to evaluate the anti bacterial activity by using Muller Hinton agar ${ }^{8,9}$. Sterile filter paper disc (Whatman No.1, $6 \mathrm{~mm}$ ) was impregnated with $100 \mu \mathrm{L}$ of each extract $(5$ and $10 \mathrm{mg} / \mathrm{ml})$ to give a final concentration of $0.5 \mathrm{mg} / \mathrm{disc}$ and $1.0 \mathrm{mg} /$ disc. The discs were properly placed on already seeded Muller Hinton agar plates. Sterile DMSO served as negative control. Ampicillin and Griseofulvin were used as standard antibacterials. All the plates were incubated for $24 \mathrm{~h}$, at $37^{\circ} \mathrm{C}$. The antibacterial activity was interpreted by determining diameter of zone of inhibition (in $\mathrm{mm}$ ). Each extract was assayed in triplicate ${ }^{10,11}$.

\section{Minimum inhibitory concentration (MIC)}

MIC of all extract of Machilus macrantha was determined against Staphylococcus aureus NCIM 2079, Salmonella typhi NCIM 2217, Escherichia coli NCIM 2065, Pseudomonas aerugenosa NCIM 2200, while the fungal strains are Candida albicans NCIM 3471 and Aspergillus niger NCIM 3452 using the two fold serial micro dilution method. ${ }^{12}$ The concentration used in the experiment ranging from $7 \mathrm{mg} / \mathrm{ml}$ to $0.0781 \mathrm{mg} / \mathrm{ml}$. The tested extracts were added to sterile micro titer plates containing Muller Hinton agar. In each plate diluted bacterial suspension (final inoculum of $1 \times 10^{8}$ bacteria/ ml) were added.

Table 1: Qualitative Chemical Tests of Machilus macrantha Bark Extracts

\begin{tabular}{|c|c|c|c|c|c|}
\hline Chemical Tests & Pet. ether extract & Chloroform extract & Acetone extract & Ethyl acetate & Aqueous extrac \\
\hline Tests for Alkaloids: & + & ++ & - & + & + \\
\hline Test for Carbohydrates & - & - & + & + & ++ \\
\hline Tests for Mucilage & - & - & + & + & + \\
\hline Tests for phenolic and tannins & - & - & ++ & ++ & + \\
\hline Tests for steroids and triterpenoid & ++ & ++ & + & - & - \\
\hline Test for Proteins & - & - & - & - & + \\
\hline Test for oils and fats & + & + & - & - & - \\
\hline
\end{tabular}

Table 2: Antimicrobial Activity of Machilus macrantha Stem Bark Extracts

\begin{tabular}{|c|c|c|c|c|c|c|c|c|}
\hline \multicolumn{2}{|r|}{ Samples } & \multirow{2}{*}{$\begin{array}{l}\text { Conc. } \\
\mathrm{mg} / \mathrm{ml}\end{array}$} & \multicolumn{6}{|c|}{ Diameter of Zone of inhibition( $\mathrm{mm})^{\mathrm{a}}$} \\
\hline \multirow{11}{*}{$\begin{array}{c}\text { Extracts } \\
\mathrm{mg} / \mathrm{ml}\end{array}$} & & & S. aureus & S. typhi & E. coli & P. aeruginosa & C. albicans & A. niger \\
\hline & \multirow[t]{2}{*}{ Pet ether } & 5 & 12 & $14 *$ & $18^{*}$ & $16^{*}$ & 10 & 08 \\
\hline & & 10 & $19 * *$ & $19 * *$ & $23 * *$ & $21 * *$ & $18 *$ & $13 *$ \\
\hline & \multirow[t]{2}{*}{ Chloroform } & 5 & 08 & $17 *$ & $14 *$ & $19 *$ & 11 & 10 \\
\hline & & 10 & $17 *$ & $22 * *$ & $19 *$ & $25 * *$ & $17 *$ & $17 *$ \\
\hline & \multirow[t]{2}{*}{ Acetone } & 5 & $17 *$ & 10 & $16^{*}$ & $20 *$ & 12 & 09 \\
\hline & & 10 & $22 * *$ & $18^{*}$ & $21 * *$ & $22 * *$ & $18 * *$ & $14^{*}$ \\
\hline & \multirow[t]{2}{*}{ Ethyl acetate } & 5 & $17 *$ & 12 & $18 *$ & $16^{*}$ & 12 & 10 \\
\hline & & 10 & $24 * *$ & $16^{*}$ & $22 * *$ & $19 *$ & $16^{*}$ & $18 * *$ \\
\hline & \multirow[t]{2}{*}{ Aqueous } & 5 & 10 & $13 *$ & $14 *$ & $17 *$ & --- & --- \\
\hline & & 10 & $16^{*}$ & $18 *$ & $17 *$ & $23 * *$ & $13 *$ & 09 \\
\hline \multirow{2}{*}{$\begin{array}{c}\text { Standards } \\
\mu \mathrm{g} / \mathrm{ml}\end{array}$} & Ampicillin trihydrate & & $26^{* *}$ & $22 * *$ & $24 * *$ & $28 * *$ & $\begin{array}{ll}-- \\
\end{array}$ & $\begin{array}{ll}--- \\
\end{array}$ \\
\hline & Griseofulvin & & --- & --- & --- & --- & $26 * *$ & $24 * *$ \\
\hline
\end{tabular}

a-Values are average of three determinations; statistically significant when compared with control group by Student ' $\mathrm{t}$ ' test $* \mathrm{P}<0.05$; $* * \mathrm{P}<0.01$. -- No zone of inhibition; well diameter $=6 \mathrm{~mm}$; NCIM-National Collection of Industrial Microorganisms

Table 3: Minimum Inhibitory Concentration of Machilus macrantha Stem Bark Extracts

\begin{tabular}{|c|c|c|c|c|c|c|c|}
\hline \multicolumn{2}{|c|}{ Samples } & \multicolumn{6}{|c|}{ Minimum Inhibitory Concentration (MIC) ${ }^{\mathrm{a}}$} \\
\hline \multirow{6}{*}{$\begin{array}{c}\text { Extracts } \\
\mathrm{mg} / \mathrm{ml}\end{array}$} & & S. aureus & S. typhi & E. coli & P. aeruginosa & C. albicans & A. niger \\
\hline & Pet ether & 4 & 4 & 1 & 2 & 2 & 4 \\
\hline & Chloroform & 6 & 2 & 4 & 2 & 2 & 2 \\
\hline & Acetone & 2 & 6 & 4 & 1 & 2 & 6 \\
\hline & Ethyl acetate & 2 & 4 & 2 & 2 & 2 & 4 \\
\hline & Aqueous & 2 & 4 & 2 & 2 & --- & --- \\
\hline \multirow{2}{*}{$\begin{array}{c}\text { Standards } \\
\mu \mathrm{g} / \mathrm{ml}\end{array}$} & Ampicillin trihydrate & 10 & 20 & 20 & 10 & --- & --- \\
\hline & Griseofulvin & --- & --- & --- & --- & 10 & 10 \\
\hline
\end{tabular}


The bacterial suspension was used as a positive control and the extracts in both were used as a negative control. The MIC values were taken as the lowest concentration of the extracts in wells of the micro titer plate that showed no turbidity after $24 \mathrm{~h}$ of the incubation at $37^{\circ} \mathrm{C}$. The turbidity of the wells was interpreted as visible growth of the microorganisms. Each extract was assayed in triplicate.

\section{GC-MS analysis of petroleum ether extract}

GC-Mass spectrometer-Perkin Elmer USA model Auto system XL GC interfaced to a API 20 NL based packed column with flame ionization detector and analyzerQuadruple with prefilter was used for mass spectral identification of the isolated components. Equipped with Turbo mass range up to $1200 \mathrm{amu}$, PE 5MS capillary columns $(30 \mathrm{~m} \times 0.25 \mathrm{~mm} \times 0.25 \mu \mathrm{m}$ film thick-nesses $)$ were used for GCMS. The oven temperature was maintained at $60^{\circ} \mathrm{C}$ for 5 minutes then programmed to $240^{\circ} \mathrm{C}$ at $5^{\circ} \mathrm{min}^{-1}$. The carrier gas was helium, at a flow rate of $1 \mathrm{~mL} \mathrm{~min}^{-1}$, and the injection volume was $1 \mu \mathrm{L}$. In mass spectrometry electron-impact ionization was performed at electron energy of $70 \mathrm{eV}$. Components of PE were identified by comparison of their mass spectra and retention indices with those published in NIST '98 MS computer library.

\section{RESULTS AND DISCUSSION}

Medicinal plants represent a rich source of antimicrobial agents. Medicinally, plants are used a source of many powerful and potent drugs. The extractive value of petroleum ether (40-60), chloroform, acetone, ethyl acetate and aqueous extract were found to be $2.88 \%, 2.45$ $\%, 9.01 \%, 3.2 \%$ and $9.3 \% \mathrm{w} / \mathrm{w}$ respectively. The results of phytochemical analysis showed the positive test for the presence of steroids, alkaloids, carbohydrates and tannins ${ }^{11}$. Results are tabulated in Table 1. For the antimicrobial activity, the diameter of zone of inhibition (in $\mathrm{mm}$ ) and MIC were determined. Results of antibacterial activity are reported in Table 2 and Table 3. Results obtained showed that all the extracts had significant inhibitory effect $(\mathrm{P}<0.01)$ against tested bacteria, whereas remarkable $(\mathrm{P}<0.05)$ inhibitory effect against fungi at a concentration of 5 and $10 \mathrm{mg} / \mathrm{ml}$ comparable with control and reference standard group. Tannins containing extracts like acetone and ethyl acetate significantly $(\mathrm{P}<0.01)$ inhibited growth of micro organism against $S$. aureus while chloroform and ethyl acetate extracts showed significant $(\mathrm{P}<0.01)$ inhibition against $S$. typhi, E. coli and $P$. aeruginosa at the conc. of $10 \mathrm{mg} / \mathrm{ml}$. In addition, the acetone and pet ether extracts exhibited a significantly inhibition on $C$. albicans and $A$. niger. Successive extracts of Machilus macrantha stem bark such as pet. ether (1-4 mg/ml), chloroform (2-6 $\mathrm{mg} / \mathrm{ml})$, acetone $(1-6 \mathrm{mg} / \mathrm{ml})$ and ethyl acetate extract (2$4 \mathrm{mg} / \mathrm{ml}$ ) showed concentration-dependent inhibitory activity against all the tested bacteria and fungi. The significant MIC value for the microorganisms (E. coli, $P$. aerugenosa) sensitive to the extract was $1 \mathrm{mg} / \mathrm{ml}$ while aqueous extract has shown good activity against the tested bacteria with a minimum inhibitory concentration (MIC) of $2 \mathrm{mg} / \mathrm{ml}$ but does not exhibit antifungal activity as compared with reference standard. The overall MIC of extracts was found to be in between 1-6 mg/ml. GC-MS analysis gives the idea about the presence of nature of chemical compound in the pet. ether extracts. The results showed the presence of steroidal compounds like Cholesta-4, 6-dien-3-ol, (3 bet),Stigma sterol, $\beta$-sitosterol, campesterol and Di iso eugenol-dehydro. Identification of these compounds was carried out by comparison of mass fragmentation pattern with those of standard compound by Nist library. The antimicrobial properties of the plants may be attributed to the secondary metabolites present in it. Therefore, this study suggests that active constituents, responsible for the observed activity, may be isolated and identified. However the antimicrobial activity needs to be studied using isolated pure compounds from the fractions to which the more resistant strains were susceptible in order to confirm these findings.

\section{ACKNOWLEDGEMENTS}

The author(s) are highly thankful to Dept. of Microbiology, R.C. Patel Arts and Science College, Shirpur, Dist: Dhule, India for providing experimental facilities for this study.

\section{REFERENCES}

1. Doughari JH. Antimicrobial activity of Tamarindus indica Linn. Trop J Pharma Res 2006; 5(2): 597-603.

2. Anonymous. The Wealth of India, CSIR, New Delhi 2003; 6: 204.

3. Kirtikar KR, Basu BD. Indian Medicinal Plants, Dehradun, International Books distributors 1999; 3: 2155.

4. Nadkarni KM. Indian Materia Medica. Popular Prakashan, Bombay 2001; 1: 759.

5. Gowda D Channe. Structure of an arabinoxylan from the bark of Persea macrantha (Lauraceae). Carbohydr Res 1982; 108: 261-267. http://dx.doi.org/10.1016/S0008-6215(00)81796-6

6. Tatiya AU, Hatapakki BC. Anti inflammatory activity of Machilus macrantha stem bark. Indian J. Pharm Sci 2003; 3: 240-242.

7. Bruneton J. Pharmacognosy, Phytochemistry and Medicinal Plants: Intercept Ltd; New York 1999; 2: 383.

8. Basic Laboratory Procedures in Clinical Bacteriology. World Health Organization, Jaypee Brothers, Geneva; 1991. p. 84.

9. Basri DF, Fan SH. The Potential of aqueous and acetone extracts of galls of Quercus infectoria as antibacterial agents. Indian J Pharmacol 2005; 37(1): 26- 29. http://dx.doi.org/10.4103/02537613.13851

10. Aida P, Rosa V, Blamea F, Tomas A, Salvador C. Paraguayan plants used in Traditional Medicine. J. Ethanopharmacol 2002; 16: 93-98.

11. Sriniwasan D, Permalsamy LP, Nathan S, Sures T. Antimicrobial activity of certain Indian medicinal plants in folkloric medicine. J Ethanopharmacol 2001; 94: 217-222. http://dx.doi.org/10.1016/ S0378-8741(00)00345-7

12. Pharmacopoeia of India. Controller of Publication, Ministry of Health and Family Welfare, Govt. of India, New Delhi; 1996. p. 105 .

Cite this article as:

Anil U Tatiya, Santosh S Surana, A. K. Saluja, Sanjay J Surana. Antimicrobial activity of Machilus macrantha Nees. (Lauraceae) stem bark extracts. Int. J. Res. Ayurveda Pharm. 2014;5(1):105-107 http://dx.doi.org/10.7897/2277-4343.05122 